Ulf Thyge Larsen MD, Bent Juhl MD, Ole Hein-Sørensen MD, Bent de Fine Olivarius MD

\title{
Complications during anaesthesia in patients with Duchenne's muscular dystrophy (a retrospective study)
}

The purpose of this retrospective study was to estimate the frequency and severity of anaesthetic complications in patients with Duchenne's muscular dystrophy (DMD). Forty-four boys with DMD were exposed to anaesthesia and surgery 84 times during a period of 22 years (1965-86). The procedures took place at 15 different hospitals. Retrospective examination of the case records showed: 19 cases with local analgesia without any complications, and 18 of 65 general anaesthetics with minor or more serious complications. In ten cases an increase in body temperature above $37.5^{\circ} \mathrm{C}$ was seen, five had abdominal pain and dark-coloured urine after surgery, and three had a critical perioperative course with a resemblance to malignant hyper. thermia. The complications were almost exclusively related to the use of succinylcholine. The use of succinylcholine was dispersed through all ages. Three out of the eight patients with severe complications occurred 1.5, 2.5 and 4 years before the neuromuscular disease was diagnosed. Thus an unusual course of anaesthesia in male children calls for further investigation. Although it has been stated before that succinylcholine is contraindicated in patients with Duchenne's muscular dystrophy, the drug continues to be used.

\section{Key words}

ANAESTHESIA: paediatric; COMPLICATIONS: muscular dystrophy, arrhythmia; HYPERTHERMIA: malignant.

From the Departments of Anesthesiology and Neurology, University Hospital of Aarhus, Denmark.

Address correspondence to: Dr. Ulf Thyge Larsen, Byagervej 129, DK-8330 Heder, Denmark.
Complications in connection with general anaesthesia in patients with Duchenne's Muscular Dystrophy (DMD) have been described often in the last 25 years. ${ }^{1-8}$ Patients with DMD are considered to be at risk of malignant hyperthermia, ${ }^{9}$ and pulmonary, cardiac and gastrointestinal complications have been described. ${ }^{3,5,6}$ A larger study published in 1964 included 76 patients undergoing 100 anaesthetics during a period of ten years, but only two anaesthetic complications were recorded. ${ }^{10}$ However, that study included many different types of neuromuscular disease.

The purpose of this retrospective study was to estimate the frequency and severity of anaesthetic complications in a larger group of patients with DMD and to correlate these complications with the types of anaesthesia.

\section{Methods}

The department of neuromuscular diseases at the University Hospital of Aarhus receives DMD-patients from a quarter of Denmark for diagnosis and follow-up examination. The period of investigation was from 1 January 1965 until 31 December 1986. Forty-four boys with confirmed DMD-diagnosis were included. During that period three patients died from respiratory insufficiency unrelated to anaesthesia. The age of the 41 survivors ranged from 3.9 to 23 years. All case records were examined and copies of anaesthetic charts from other hospitals were procured. The information was insufficient in six cases and was excluded.

\section{Results}

The ECG had been recorded in 37 patients on different occasions; 11 were normal, while 26 had characteristic alterations for DMD with high $R_{\mathrm{v1-2}}$ and deep $Q_{\mathrm{v} 5-6}$. Although Duchenne patients frequently have arrhythmias, especially atrial dysrhythmias, this was not seen on the present cardiograms. ${ }^{11}$

During 22 years 44 DMD-patients were subjected to 82 elective and two acute operations using local analgesia (LA) on 19 occasions and general anaesthesia (GA) on 65 


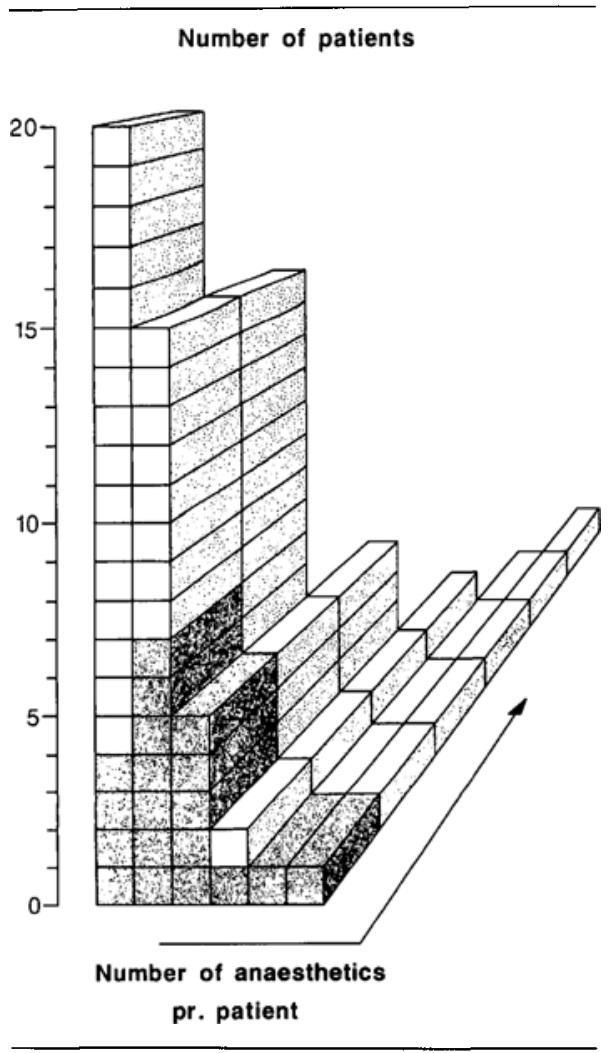

FIGURE 1 Frequency in each patient of anaesthesia with local 掣 or general $\square$ anaesthetics

(Figure 1). Table I shows the types of surgery in relation to LA and GA. Figure 2 illustrates when the individual patient was anaesthetized. Xylocaine one per cent with adrenaline or 0.25 per cent bupivacaine was used for LA. Oxygen- $\mathrm{N}_{2} \mathrm{O}$-halothane was used in 59 of the 65 GAs. Thiopentone induction of anaesthesia was used in seven

TABLE I The type of surgery in relation to local and general anaesthesia

\begin{tabular}{lrr}
\hline Muscle biopsy & 10 & 32 \\
Orthopaedic surgery & 8 & 16 \\
Abdominal surgery & 0 & 4 \\
Ear-nose-throat & 1 & 11 \\
Other surgery & 0 & 2 \\
& $\frac{0}{19}$ & $\frac{65}{2}$ \\
\hline
\end{tabular}

General anaesthesia with $\boxplus$ and without $\mathrm{日}$ suxamethonium Local analgesia $\mathbf{Q}$

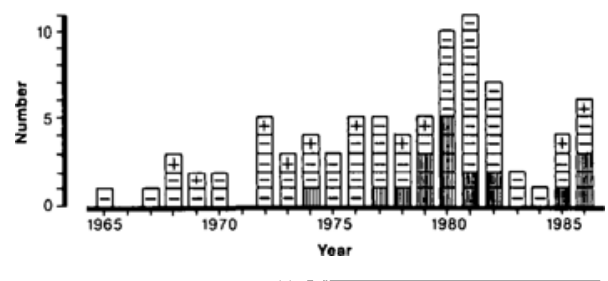

FIGURE 2

and local xylocaine supplement in two. Ketamine IM was used in only one patient, and divinylether in four.

The median age of the patients was 6.8 years, range 14 days to 17 years. Thirty-nine ( 3 LA, 36 GA) were performed at regional hospitals, 23 of them were performed before the DMD-diagnosis was suspected, and the $16 \mathrm{LAs}$ and $29 \mathrm{GAs}$ were performed with the knowledge of DMD at the University Hospital.

\section{Complications}

All LAs were carried out without any complications. During and after the 65 GAs a total of 18 atypical events was seen in 15 patients.

We identified three groups (Table II):

i Increased heart rate and rectal temperature from $37.5-38.2^{\circ} \mathrm{C}$ within a few hours of anaesthesia. The temperature was not controlled until the next morning, where it was normalized (ten patients).

ii Postoperative abdominal pain and dark-coloured urine (five patients).

iii An acute, critical course, described in the following case histories (three patients).

Two patients in group i had increased temperature on two occasions and one patient in group ii had abdominal pain and dark-coloured urine twice. The complications occurred in six of the 18 patients during the first anaesthetic, in seven during the second, in three during the third and in one during the fourth anaesthetic.

An increase in body temperature $37.5-38.2^{\circ} \mathrm{C}$ and an

TABLE II Complications and succinylcholine

\begin{tabular}{cll}
\hline & $\begin{array}{l}\text { With } \\
\text { succinylcholine }\end{array}$ & $\begin{array}{l}\text { Without } \\
\text { succinylcholine }\end{array}$ \\
\hline i & 1 & 9 \\
ii & 5 & 0 \\
iii & 3 & 0 \\
& $\frac{3}{9}$ & 5 \\
\hline
\end{tabular}


increased heart rate occurred in seven out of 50 patients anaesthetized with $\mathrm{O}_{2}-\mathrm{N}_{2} \mathrm{O}$-halothane without succinylcholine. In contrast, quite abnormal courses were seen in eight out of ten cases with succinylcholine. Precurarizing doses of non-depolarizing muscle relaxant were never used. DMD was undiagnosed in eight patients at the time of the complication. Three of these, belonging to the group of serious complications after succinylcholine, had DMD diagnosed 1.5, 2.5 and 4 years later respectively.

In otherwise uncomplicated anaesthetics cardiac arrythmia was observed only once. Ventricular ectopic beats were seen during induction of anaesthesia with halothane.

The degree of disablement, length of anaesthesia and type of surgery were not correlated to the complications. Pulmonary aspiration was not noticed, and gastric tubes were not used during or after anaesthesia.

\section{Case reports}

\section{Case 1}

A boy, aged five, had a muscle biopsy performed. Premedication was with phenobarbital and atropine and anaesthesia with $\mathrm{O}_{2}-\mathrm{N}_{2} \mathrm{O}$-halothane-meperidine was uneventful. At the age of nine he was scheduled for elongation of the Achilles tendons. Premedication was with oral diazepam $5 \mathrm{mg}$ and the anaesthetic was again $\mathrm{O}_{2}-\mathrm{N}_{2} \mathrm{O}$-halothane, but succinylcholine $37.5 \mathrm{mg}$ IV (BW $24 \mathrm{~kg}$ ) was given to facilitate tracheal intubation. The intubation was uneventful but immediately afterwards he became rigid and his lungs were difficult to ventilate. Flushing and tachycardia appeared. Verapamil $0.75+$ $0.75 \mathrm{mg}$ IV decreased heart rate, but the tachycardia reappeared and was followed by ventricular fibrillation. Sinus rhythm reappeared after xylocaine, phenylephrine hydrochloride, calcium, sodium bicarbonate and stopping anaesthesia. The temperature was $37.5^{\circ} \mathrm{C}$ postoperatively, and arterial blood gas analysis was normal. The urine was not examined. The patient was discharged the next day. The operation was performed six months later with an uneventful LA.

\section{Case 2}

A boy aged five was scheduled for adeno-tonsillectomy. His brother had DMD. Premedication was with morphinescopolamine and anaesthesia was maintained with $\mathrm{O}_{2}$ $\mathrm{N}_{2} \mathrm{O}$-halothane after succinylcholine $50 \mathrm{mg} \mathrm{IM}$ (BW 12 $\mathrm{kg}$ ) for tracheal intubation. The intubation was uneventful, but 20 minutes later the patient became pale, clammy and cyanotic with deteriorating respiration and irregular tachycardia. The temperature was $37.8^{\circ} \mathrm{C}$. The urine was turbid and red-brown without erythrocytes or bacteria. A few hours later the patient's condition had returned to normal. The diagnosis of DMD was not made until 1.5 years later. Since then he has had one general anaesthetic with $\mathrm{O}_{2}-\mathrm{N}_{2} \mathrm{O}$-halothane and one local anaesthetic without complications.

Case 3

This boy had three GAs with $\mathrm{O}_{2}-\mathrm{N}_{2} \mathrm{O}$-halothane in his first year of life for redressing of his feet (congenital club foot). At the age of 3.5 years he was scheduled for elongation of the Achilles tendons. Premedication, with oral diazepam and atropine IV, was given at the beginning of the anaesthetic with $\mathrm{O}_{2}-\mathrm{N}_{2} \mathrm{O}$-halothane-meperidine and succinylcholine $20 \mathrm{mg} \mathrm{IV} \mathrm{(BW} 15 \mathrm{~kg}$ ). The duration of anaesthesia was 85 minutes. Immediately postoperatively the patient was cyanotic, dull, sweating with a heart rate of $170 \mathrm{bpm}$, tachypnoea and retention of secretions. The temperature was $37.5^{\circ} \mathrm{C}$. He was discharged two days later. The diagnosis of DMD was not confirmed until 2.5 years later with muscle biopsy during an uncomplicated anaesthetic with $\mathrm{O}_{2}-\mathrm{N}_{2} \mathrm{O}$-halothane. At the age of ten, he had a reoperation on the Achilles tendons using LA without any complications.

\section{Discussion}

Each year 10-20 boys with DMD are born in Denmark. Intensive treatment of pulmonary problems probably has increased their lifespan. In 1965 the expected survival of these patients was less than 18 years, and the total number of patients with DMD in Denmark was 163.12

The frequency of anaesthesia for our group of patients varied from 0 to 11 per year with a median of four (Figure 1). The patients were treated at $\mathbf{1 5}$ different hospitals, which explains the difficulties in conducting a prospective study. Although information often is insufficient in retrospect some conclusions can be drawn. Local anaesthesia is without complications in DMD-patients and should be used more often, depending on the type of surgery and the age of the child. Only one quarter of the muscle biopsies and one third of the orthopaedic operations were performed using LA (Table I).

The modest increase in body temperature and the tachycardia might be "a normal reaction" to general anaesthesia, ${ }^{13}$ but these signs have been suggested as precursors for respiratory problems postoperatively. ${ }^{1,5}$ The more severe complications with abdominal pain and dark-coloured urine are probably manifestations of thabdomyolysis with myoglobinuria, which has been related to the use of succinylcholine in DMD-patients. $1,3,5,7,14$ The more serious complications (cases 2 and 3) represent respiratory insufficiency caused by weakness of the respiratory muscles. Smith and Bush have described respiratory insufficiency several days following otherwise uncomplicated anaesthesia. ${ }^{3}$ 
Case 1 has many similarities to malignant hyperthermia (MH). Several authors have reported similar case histories, where subsequent muscle biopsy showed positive reactions to halothane and caffeine. $5,9,14$ DMD-patients have an increased risk of developing $\mathrm{MH} .{ }^{9}$ The reason might be the increased intracellular calcium concentration, which is a part of the destructive process in DMD. ${ }^{15}$ Metabolic acidosis and very high body temperature are seldom seen in DMD-patients, because the abnormal metabolic process of MH acts on a scanty musculature. ${ }^{14}$

Adverse reactions have been observed following anaesthesia with halothane alone, but usually following the use of succinylcholine..$^{5-8,13,14,16-18}$ Although this has been known for the last 25 years, it is apparently not common knowledge. The succinylcholine exposures in this material were scattered over the period of observation (Figure 1). The follow-up examinations after adverse reactions to general anaesthesia were often incomplete, and some of the patients were exposed again to the same type of anaesthesia. Adverse reactions to general anaesthetics might be the first hint of an undiagnosed DMD.

If general anaesthesia is necessary special care is recommended. ${ }^{19,20}$

\section{Conclusions}

In a retrospective study 84 anaesthetics were administered to 44 patients with DMD and 18 atypical courses were observed. The complications on a number of occasions occurred several years $(1.5-4)$ before the diagnosis of DMD was made. In ten general anaesthetics succinylcholine was used, and nine of them were associated with complications. Succinylcholine is contraindicated in anaesthesia for these patients. It is therefore recommended that patients with DMD be considered as patients at risk of developing malignant hyperthermia during GA.

\section{Acknowledgments}

We express our thanks to the departments who have been helpful in collecting the case reports. Special thanks are extended to Miss $\mathbf{K}$. Stranddorf, the neurologic department, Aarhus Kommunehospital.

\section{References}

1 Boba A. Fatal postanaesthetic complications in two muscular dystrophic patients. J Pediatr Surg 1970; 5: $71-5$.

2 Sethna NF, Rockoff MA. Cardiac arrest following inhalation induction of anaesthesia in a child with Duchenne's muscular dystrophy. Can Anaesth Soc J 1986; 33: 799802.

3 Smith $C L$, Bush $G H$. Anaesthesia and progressive muscular dystrophy. Br J Anaesth 1985; 57: 1113-8.
4 Wislichi $L$. Anaesthesia and postoperative complications in progressive muscular dystrophy. Anaesthesia 1962; 17: 482-7.

5 Brownell AKW, Paasuke RT, Elash A et al. Malignant hyperthermia in Duchenne muscular dystrophy. Anesthesiology 1983; 58: 180-2.

6 Kelfer HM, Singer WD, Reynolds RN. Malignant hyperthermia in a child with Duchenne muscular dystrophy. Pediatrics 1983; 71: 118-9.

7 Genever EE. Suxamethonium-induced cardiac arrest in unsuspected pseudohypertrophic muscular dystrophy. Br J Anaesth 1971; 43: 984-6.

8 Solares $G$, Herranz $J L$, Sanz MD. Suxamethoniuminduced cardiac arrest as an initial manifestation of Duchenne muscular dystrophy. Br J Anaesth 1986; 55: 576.

9 Rosenberg H, Heimann-Patterson T. Duchenne's muscular dystrophy and malignant hyperthermia: another warning. Anesthesiology 1983: 59: 362.

10 Cobham IG, Davis $H S$. Anaesthesia for muscle dystrophy patients. Anesth Analg 1964; 43: 22-9.

11 Perloff JK. Cardiac rhythm and conduction in Duchenne muscular dystrophy. J Am Coll Cardiol 1984; 3: 1263-8.

12 Leth $A$, Wulff $K$, Corfitsen $M$, Elmgreen J. Progressive muscular dystrophy in Denmark. Acta Paediatr Scand 1985; 74: 881-5.

13 Ellis FR. Inherited muscle disease. $\mathrm{Br} \mathrm{J}$ Anaesth 1980; 52: 153-64.

14 Oka S, Igarashi Y, Takagi A et al. Malignant hyperpyrexia and Duchenne muscular dystrophy: a case report. Can Anaesth Soc J 1982; 29: 627-9.

15 Rowland LP. Biochemistry of muscle membranes in Duchenne muscular dystrophy. Muscle Nerve 1980; 3: 3-20.

16 Cooperman $L H$. Succinylcholine-induced hyperkalemia in neuromuscular disease. JAMA 1970; 213: 1867-71.

17 Tobey RE, Jacobsen PM, Kahle CT, Clubb RJ, Dean $M A$. The serum potassium response to muscle relaxants in neural injury. Anesthesiology 1972; 37: 332-7.

18 Gronert GA. Malignant hyperthermia. Anesthesiology 1980; 53: 395-423.

19 Mercier C, Poulain D, Dubos J, Martin L, Rideau Y, Glorion $B$. Anesthesie chez l'enfant myopathe. Cah Anesthesiol 1984; 5: 349-53.

20 Larsen UT, Juhl B. Anaesthesia for persons with muscle dystrophia. Ugeskr Laeger 1988; 150: 1965-8. 
Résumé

Cette étude rêtrospective visait à déterminer l'incidence et la gravité des complications survenant en cours d'anesthésie chez les victimes de la dystrophie musculaire de Duchenne (DMD). Nous avons revu les dossiers de 84 interventions faites chez 44 garçons atteints, dans 15 hôpitaux entre 1965 et 1986. Les 19 interventions sous anesthésie locale s'étaient déroulées sans problème mais nous avons identifié 18 complications lors des 65 anaesthésies générales. En dix occasions, la température s' etait élevée au deld de $37.5^{\circ} \mathrm{C}$, accompagnée dans cinq cas, de douleurs abdominales et d' urines foncées après l' intervention et dans trois cas, d'une période péri-opératoire mouvementée ressemblant a de l'hyperthermie maligne. Ces complications étaient systématiquement associées a l'usage de la succinylcholine, prévalent quel que soit l'age. Trois des huit incidents majeurs se sont produits $1.5,2.5$ et 4 ans avant que le diagnostic de DMD ne soit posé, ainsi, toute anesthesie compliquée chez un garçon devrait éveiller les soupçons. Par ailleurs, nous déplorons l'usage persistant de la succinylcholine chez les malades atteints de dystrophie musculaire de Duchenne et ce, malgré les nombreuses mises en garde. 